\title{
Indian Banking and Information Content of EVA and Traditional Measures
}

\author{
Dr. Jasvir S. Sura, Ms. Anju Lather \\ Assistant Professor, Kurukshetra University Post Graduate Regional Centre, Jind, Haryana. \\ Assistant Professor, Kurukshetra University Post Graduate Regional Centre, Jind, Haryana.
}

\begin{abstract}
The rationale behind the study lies in the facts that about superiority of EVA over traditional matrices is mixed and were focused on manufacturing sectors. Hence, relationship between the Market Value Added (MVA), EVA, and accounting performance measures such as net earnings (PAT), earning per share $(E P S)$, return on investment (ROI), return on net worth (RONW), and return on capital employed, Economic Value Added (EVA), and Market value Added (MVA) has not been grossly researched to Indian Banking Sector. The data has been collected through most worthy 'PROWESS' database of Centre for monitoring Indian Economy (CMIE). The reference period of the study is fourteen financial years i.e. 2000-2013.The multiple regression and Biddle's et. al. (1997), Bao and Bao (1998) approach is selected for studying relative and incremental informational of EVA vis-à-vis other traditional financial performance measures. The result of cross-section regression reveals that earning (PAT) having highest explanatory power than EVA, ROI and EPS to explain market value added by sample banks. Fourth, the relative and incremental informational test present that The PAT having highest relative explanatory (66.7 percent) power do explain market value added as compared to EVA, ROI, EPS, ROCE alone and the relative informational content of EVA is lower than PAT, which, accounting for only 57.4 present of variation in market value added (MVA). Thus, the usefulness of EVA for decision making can't be ruled out based on the results and it can be used as an internal as well as external performance measurer. As Solomon (1965) suggested that residual income be used as an internal performance measure and Anthony (1973, 1982, and 1982) suggested that it is suitable to measure external performance.
\end{abstract}

Keywords: EVA, MVA, Traditional financial performance measures, Indian banking industry.

Article Type: Research paper

\section{Backdrop}

Traditionally, the financial performance has been valued by matrices in financial statements, such as net profit, earning per share, return on investment, and return on assets, etc. This information is used by corporate managers, owners (shareholders), and investors to measure and predict current as well as future firm performance. But these traditional accounting-based performance measures are often criticized for not taking into consideration the total cost of capital and for also being unduly influenced by accrual-based accounting conventions. Due to the limits of the traditional matrices in measuring the performance, many new value based performance measures have been emerged to the performance evaluation systems since mid 80s in 20 century, such as EVA (Economic Value Added), MVA (Market Value Added), CVA (Cash Value Added), and CFROI (Cash Flow Return on Investment). EVA (Economic Value Added) emerged as the most popular value based performance measures as Peter Druker (1995) in the Harward Business Review suggest that EVA's growing popularity reflects, amongst other things the demand of the information age for a measurement of the total factor productivity.

The origin of EVA (Economic Value Added) has been tracked from Hamilton (1777), and Marshall (1890) work, who explained that to create wealth they must earn more than the cost of supplied funds. In 1920's General Motors (GM) applied this concept, and in 1950 General Electric (GE) labeled it "residual income" and applied it as performance measure to their decentralized divisions (Stewart, 1994). From the inception to till date there is growing concern debate about the validity, adoptability and superiority of the concept. The very first question arise that whether, it is internal performance measure or external performance measure. Solomon (1965) suggested that residual income be used as an internal performance measure and Anthony (1973, 1982, and 1982) suggested that it be an external performance measure.

In 1991 Stern Stewart \& Company revised the computation of residual income through a series of accounting adjustments and relabeled it EVA. EVA is a measures whether operating profit is enough compared to the total cost of capital. Stewart defined (1990) EVA as net operating profit after tax (NOPAT) subtracted with capital charge. 


\section{Research Methodology}

After reviewing existing literature in the area of financial performance measures, a number of important points come out. First, the concept of Economic Value Added (EVA) have been relabeled from well established microeconomic concept of mid-ninth 'Residual Income' by revising a series of accounting adjustments by Stern Stewart \& Co. of USA.

Second, it is an internal (Solomon, 1965) and external (Anthony, 1982) proprietary (Registered by Stern Stewart \& Co.) financial performance measures.

Third, the literature regarding EVA has been giving assorted view, as stated by Lehen and Makhija (1997), "EVA is seen by its proponents as providing the most reliable year-to-year indicator of a market-based performance measure known as Market Value Added... Despite wide interest in EVA, little is known empirically about the efficacy of this measure versus other measures of performance... The evidence from these studies is mixed, however, and has not be resolved the debate over performance measures". Maditinos, et. al (2009), Biddle, et. al. (1997), Tong et.al (2009), Dimitris (2007), Ismail (2006), Ralph (2006), Kim (2006), Bao and Bao (1999), Biddle et al., (1999) also arrived at similar conclusion. Dodd and Chen (1997) similarly raised another dimensions of EVA and conclude that Economic value Added has been acclaimed to the most recent and exciting innovation in company performance measures. They gave three conclusions from the examination: (a) although improving EVA performance is associated with a higher stock return, the association is not as perfect as acclaimed by EVA advocates (b) EVA is more powerful than traditional measures of accounting profit in explaining stock return; however, accounting earnings are still of significant incremental information value in addition to EVA; and (c) not only is EVA similar to residual income in concept, they are empirically comparable. The profounder and some academician like Anand, et. al. (1998), Banerjee and Jain (1998), Ehrbar, A. (1998), Pattanayak and Mukherjee (1998), Bacidore, et. al. (1997), Banerjee (1997), and Teitebaum (1997) etc. also join thought of Dodd and Chen (1997).

TABLE NO.-1 SUMMARY OF LITERATURE REVIVED

\begin{tabular}{|c|c|c|c|c|}
\hline Name of Author (s)/Year of Publication & $\begin{array}{l}\text { Favoring } \\
\text { EVA }(\sqrt{ })\end{array}$ & $\begin{array}{c}\text { Not } \\
\text { Favoring } \\
\text { EVA }(\sqrt{ })\end{array}$ & Journals/Books/conferences/sources & $\begin{array}{l}\text { Origin of the } \\
\text { Study }\end{array}$ \\
\hline Abdeen, and Haight (2000) & & $\sqrt{1}$ & The Journal of Applied Business Research & USA \\
\hline Acheampong and Wetzstein (2001) & & $\sqrt{1}$ & Social Science Research Network Electronic Paper Collection & UK, France. \\
\hline Anand, Garg, and Arora, (1998) & $\sqrt{ }$ & & The Management Accountant & India \\
\hline Bacidore, Boquits, Milboum, and Thakor (1997) & $\sqrt{ }$ & & Financial Analysts Journal & USA \\
\hline Banerjee (1997) & $\sqrt{ }$ & & The Management Accountant & India \\
\hline Banerjee and Jain (1998) & $\sqrt{ }$ & & Paradigm & India \\
\hline Bao and Bao (1998) & $\sqrt{ }$ & & Journal of Business Finance and Accounting & USA \\
\hline Bao and Bao (1999) & $\sqrt{ }$ & & Financial Analysts Journal & USA \\
\hline Biddle (1998) & & $\sqrt{ }$ & Managerial Finance & USA \\
\hline Biddle, Bowen and Wallace (1997) & & $\sqrt{1}$ & Journal of Accounting and Economics & USA \\
\hline Biddle, Bowen and Wallace (1999) & & $\sqrt{1}$ & Journal of Applied Corporate Finance & USA \\
\hline Both (1997) & $\sqrt{ }$ & & Management Accounting & USA \\
\hline Buekette and Hedley (1997) & $\sqrt{ }$ & & The CPA Journal & USA \\
\hline Chang (1997) & $=$ & $=$ & Chemical Market Reporter & USA \\
\hline Chen and Dodd (1997) & & $\sqrt{ }$ & Journal of Managerial Issues & USA \\
\hline Conley (1995) & & $\sqrt{1}$ & Journal of Commerce and Management, & USA \\
\hline Dimitris and Christos (2007) & & $\sqrt{ }$ & European Financial Management & Greek \\
\hline Dodd and Chen (1997) & & $\sqrt{ }$ & Business and Economic Review & USA \\
\hline Ehrbar(1998) & $\sqrt{ }$ & & John Wiley \& Sons & USA \\
\hline Femandez $(2001)$ & & $\sqrt{ }$ & Social Science Research Network Electronic Paper Collection & USA \\
\hline Fodil, Zeghal, and Andaleeb (2007) & $\sqrt{ }$ & & The Journal Corporate Governance & Canada \\
\hline George (2007) & $\sqrt{ }$ & & The Journal of Management Decision & Canada \\
\hline Grant (1996) & $\sqrt{ }$ & & Journal of Financial Management & USA \\
\hline Griffith (2006) & & $\sqrt{ }$ & Journal of Investing & USA \\
\hline Irala (2005) & & $\sqrt{1}$ & Journal of Accounting and Finance & India \\
\hline Ismail (2006) & & i & International Journal of Managerial Finance & UK \\
\hline $\operatorname{Kim}(2006)$ & & $\sqrt{ }$ & Journal of Hospitality \& Tourism Research & Korea \\
\hline Lehen and Makhija (1997) & $\sqrt{ }$ & & Journal of Applied Corporate Finance & USA \\
\hline Lehn and Makkhija (1996) & $\sqrt{ }$ & & The Journal of Strategy and Leadership & USA \\
\hline Leong, Marco and Janis (2009) & $\sqrt{1}$ & & Review of Accounting and Finance & USA \\
\hline Luber (1996) & $\sqrt{ }$ & & Fortune & USA \\
\hline Maditinos, Zeljko, and Nikolaos (2009) & & $\sqrt{ }$ & Journal of Modeling in Management & Greek \\
\hline Malik (2004) & $=$ & $=$ & The Indian Journal of Commerce & India \\
\hline McConville (1994) & & $\sqrt{ }$ & Management Accountant & UK \\
\hline Mir and Souad (2008) & $\sqrt{ }$ & & Corporate Governance & USA \\
\hline O'Byme (1996) & $\sqrt{1}$ & & Journal of Applied Corporate Finance & USA \\
\hline Padgett (1996) & $\sqrt{ }$ & & American Bankers & USA \\
\hline Pal and Garg (2004) & $\sqrt{ }$ & & The Indian Journal of Commerce & India \\
\hline Pattanayak and Mukherjee (1998) & & $\sqrt{ }$ & The Chartered Accountant & India \\
\hline Paulo (2010) & & $\sqrt{1}$ & International Joumal of Law and Management & UK \\
\hline Peixoto (2002) & & $\sqrt{ }$ & Social Science Research Network Electronic Paper Collection & Portugal \\
\hline Peterson and Peterson (1996) & $\sqrt{ }$ & & The Research Foundation of the Institute of CFA & USA \\
\hline Ralph (2006) & & $\sqrt{ }$ & Review of Accounting and Finance & USA \\
\hline Riahi-Belkaoui (1996) & & $\sqrt{1}$ & Advances in Quantitative Analysis of Finance and Accounting & USA \\
\hline Robertson and Batsakis (1999) & $\sqrt{ }$ & & Paper presented at AAANZ Annual Conference & USA \\
\hline Rogerson (1997) & $\sqrt{1}$ & & Journal of Political Economy & USA \\
\hline Stewart (1994) & $\sqrt{1}$ & & Journal of Applied Corporate Finance & USA \\
\hline Stewart (1991) & $\sqrt{ }$ & & Harper & USA \\
\hline Teitebaum (1997) & $\sqrt{ }$ & & Fortune & USA \\
\hline Todd (1997) & $\sqrt{ }$ & & Business Standard & USA \\
\hline Tong, Chuang, and Xiaoke(2009) & $\sqrt{ }$ & & IEEE Explore & China \\
\hline Uyemural Kantor, and Petit, (1996) & $\sqrt{ }$ & & Journal of Applied Corporate Finance & USA \\
\hline
\end{tabular}


Fourth, most of studies on EVA appear from the developed countries like UK, Canada, Germany, Australia, and France etc. and considering only manufacturing sector.

The inherent short-coming of the reviewed literature gives future directions for research. There is obvious requirement to study efficacy of EVA for service sector particularly banking. The available empirical studies have been conducted with reference to developing country and most of studies were considering less numbers of traditional matrices, as well small size of sample. So, it is apparent need to examine usefulness, awareness of EVA vis-à-vis traditional financial performance measures for Indian Banking Industry.

The inherent short-coming of the reviewed literature gives future directions for research. There is obvious requirement to study efficacy of EVA for service sector particularly banking. The available empirical studies have been conducted with reference to developing country and most of studies were considering less numbers of traditional matrices, as well small size of sample. So, it is apparent need to examine usefulness, awareness of EVA vis-à-vis traditional financial performance measures for Indian Banking Industry.

\section{Objectives Of The Study}

The rationale behind the study lies in the facts that about superiority of EVA over traditional matrices is mixed and were focused on manufacturing sectors. Hence, relationship between the Market Value Added (MVA), EVA, and accounting performance measures such as net earnings (PAT), earning per share (EPS), return on investment (ROI), return on net worth (RONW), and return on capital employed, Economic Value Added (EVA), and Market value Added (MVA) has not been grossly researched to Indian Banking Sector. With this broad objective in mind, the present study intends to achieve the following specific objectives:

(i) to study the informational content of EVA and traditional performance measurers to explain market value;

(ii) to study and establish cause and effect relationship between MVA and other select financial variables;

\section{HYPOTHESIS}

In synchronization with the above-mentioned objectives, the study intends to test the following null-hypotheses $\left(\mathrm{H}_{0 \mathrm{~s}}\right)$ :

$\mathbf{H}_{001}$ The distribution is asymmetrical for study variables under reference (MVA, EVA, PAT, EPS, ROCE, RONW, and ROI)

$\mathbf{H}_{\mathbf{0 0 2}}$ The association between select dependent variable is not significantly strong.

$\mathbf{H}_{003}$ Economic Value Added (EVA) provides information contents, useful in explaining the variability of market value which is not incorporated in traditional financial variables.

$\mathbf{H}_{\mathbf{0 0 4}}$ Economic Value Added (EVA) and other select traditional financial variable does not Granger cause Market Value Added.

\section{Selection and Computation of Variables}

The present research in hand identified a number of key financial variables for the purpose of achieving stated objectives. These variables are EVA, MVA, ROCE, RONW, EPS, and ROI. Computation of these variables was made for period of fourteen years. A concise explanation of these select variables for banks is outlined below:

Economic Value Added (EVA): In 1991 Stewart revised the computation of residual income through a series of accounting adjustments and relabeled it EVA. EVA is a measures whether operating profit is enough compared to the total cost of capital. Stewart defined (1991) EVA as net operating profit after tax (NOPAT) subtracted with capital charge. Mathematically Stewart thrashes out EVA model as:

$$
\mathrm{EVA}_{\mathrm{t}} \quad=\quad \mathrm{NOPAT}_{\mathrm{t}}-\left(\mathrm{WACC}_{\mathrm{t}} * \mathrm{IC}_{\mathrm{t}-1}\right)
$$

Where in equation 1:

$$
\begin{aligned}
& \text { NOPAT }=\quad \text { Net operating profit after tax } \\
& =\quad \text { Earnings before interest and tax } *(1-\text { corporate Tax rate }) \\
& \text { WACC }=\quad \text { Weighted average cost of capital } \\
& \text { IC } \quad=\quad \text { Invested capital }
\end{aligned}
$$

EVA also equivalently expressed as:

$$
\mathrm{EVA}_{\mathrm{t}}=\left(\mathrm{ROIC}_{\mathrm{t}}-\mathrm{WACC}_{\mathrm{t}}\right) * \mathrm{IC}_{\mathrm{t}-1}
$$

Where in equation 2:

$$
\begin{array}{lll}
\text { ROIC } & = & \text { Return on invested capital } \\
\text { WACC } & \text { Weighted average cost of capital } \\
\text { IC } & = & \text { Invested capital }
\end{array}
$$

Equivalently, if return of return is defined as NOPAT/Capital, this turns into a perhaps more revealing 
expression:

EVA

Where in equation 3:

Rate of return =

(Rate of return - cost of capital) * capital

Capital = Total balance sheet minus noninterest bearing debt in the beginning of the

Cost of capital $=$ year.

Cost of equity * proportion of equity from capital + cost of debt * Proportion of debt from capital (1- tax rate)

For financial or banking company NOPAT represents the after tax operating profit before financing cost and non-cash expenses. So, the following formula has been used to calculate NOPAT of banking companies as proposed by Calabrese, V. J. (1999):

$\begin{array}{ll}= & \text { Net income to common shareholders } \\ \text { Plus } & \text { Loan Loss Provisions (In excess of net Loan charge off) } \\ \text { Plus } & \text { Preferred Dividends } \\ \text { Plus } & \text { Goodwill Amortization } \\ \text { Plus } & \text { Charge in capitalized R\&D expenditures } \\ \text { Plus } & \text { Extra ordinary losses (Minus Gains) after taxes } \\ \text { Plus } & \text { Security losses (Minus Gains) after taxes }\end{array}$

Invested capital also called economic capital is described as economic value of all funds invested in a business. It composed of quantum of total equity in circulation and quantum of total debts raised. For the financial and banking company invested capital (IC) has to calculate as (Calabrese, V. J., 1999):

Minus
Plus
Plus
Plus
Plus
Plus

Banks Net Assets at the beginning of the year

Marketable securities construction in progress

Non-Capitalized lease is added to net property and equipments

Bad debts reserves (NPA)

LIFO reserve is added

Cumulative amortization of goodwill, and

Cost of Debt $\left(\mathrm{K}_{\mathrm{d}}\right)$ has been computed as:

Research and Development expenses.

$$
\mathrm{K}_{\mathrm{d}} \quad=\frac{\text { Total Intrest Expenses } \times(1-\text { Effective Tax Rate })}{\text { BeginningTotal Borrowings }}
$$

While calculating beginning borrowing all deposits as well as long term borrowing have to be including, as all debt (deposits and borrowings) are interests bearing. Therefore, interests paid in the financial year have to consider as a total interest expenses.

The cost of equity $\left(\mathrm{K}_{\mathrm{e}}\right)$ can be calculated using Capital Assets Pricing Model (CAPM). According to this model, $\mathrm{K}_{\mathrm{e}}$ is the shareholder expected return and this expected return $\left(\mathrm{R}_{\mathrm{i}}\right)$ is as follows:

$$
\begin{array}{lll}
\mathrm{R}_{\mathrm{i}}= & \mathrm{R}_{\mathrm{f}}+\beta_{\mathrm{i}}\left(\mathrm{R}_{\mathrm{m}}-\mathrm{R}_{\mathrm{f}}\right) \\
\text { Where, } & = & \text { risk free rate of return } \\
\mathrm{R}_{\mathrm{f}} & = & \begin{array}{l}
\text { Market rate of return, and } \\
\mathrm{R}_{\mathrm{m}}
\end{array} \\
\beta_{\mathrm{i}} & = & \text { Sensitivity of the share price in relation to market return. }
\end{array}
$$

In India 364 days Treasury bill (T-bill) return has been considered as proxy for risk free rate of return.

The market return can be calculated using the daily closing value of Bank Index. The market returns measured as the continuously compound daily percentage change in the average price of bank index in order to avoid the influence of extreme values. The daily market return has been calculated by taking logarithm of prices instead of:

Where,

$$
\mathbf{R}_{\mathrm{t}}=\frac{\mathbf{P}_{t} \mathbf{P}_{t_{11}}}{\mathbf{P}_{\mathrm{t}_{1}}}
$$

$$
\begin{array}{lll}
\mathrm{R}_{\mathrm{t}} & = & \text { Daily bank Index return } \\
\mathrm{P}_{\mathrm{t}} & = & \text { Current Index closing price } \\
\mathrm{P}_{\mathrm{t}-1} & = & \text { Previous day closing price. }
\end{array}
$$

The $\beta_{\mathrm{i}}$ coefficient in the standard regression equation (referred as to beta in this case) measures the sensitivity of dependent variable to per unit change in independent variable.

For the purpose of ascertaining the cost of equity, the individual bank equity share price has been taken as the depended variable and the return on the market (computed as daily return of bank index) has been taken as the independent variable. To find out receptiveness of individual bank's equity return (taken as proxy for the cost of equity) to the market rate of return, the Beta coefficient has been calculated as follows: 


$$
\begin{array}{ll}
\text { Where, } & \boldsymbol{\beta i}=\frac{\mathbf{C O V i m}}{\boldsymbol{\sigma}_{\mathbf{m}}^{2}} \\
\beta_{\mathrm{i}} & =\quad \begin{array}{l}
\text { the beta of the security in the question, } \\
\mathrm{COV}_{\mathrm{im}}
\end{array}=\begin{array}{l}
\text { covariance between return of the bank equity and market return of the bank } \\
\text { index } \\
\text { variance of the market return. }
\end{array}
\end{array}
$$

Market Value Added (MVA): The MVA explains the value added to a particular share over its book value. It enlightens how much value a shareholder has added to his wealth, which he has invested in the share. Accordingly, a bank with an objective of enhancing the shareholders' wealth should attempt to capitalize on its MVA. MVA can be estimated by subtracting the book value of its shares from the market value of its share.

MVA = Market Value of Stock - Equity capital Supplied by shareholders.

$=(365$ days average market price of share $) \times($ No. of Share outstanding $)-$ Total Common Equity.

$=365$ days average market capitalization minus paid-up equity capital

It is silent that EVA helps in pushing up the MVA of an organization. As a result, EVA can be considered as an internal measure and MVA as an external measure of a bank's performance. For the purpose of analysis in present study MVA has been considered as a dependent variable, that is, its value depend up on other independent variables viz., EVA, ROIC, ROWN, EPS, and PAT etc.. A brief description of each these independent variables has been placed in the following snippets.

Return on Capital Employed (ROCE): In the conventional accounting, for calculating profitability, ROCE is considered as the most fitting method for calculating long-term profitability. This is calculated as:

$$
\text { ROCE }=\quad \frac{\text { Profit after Taxes(Net of Non }- \text { recurring Items) }}{\text { Average Capital Employed }} \times 100
$$

Accordingly, counting ROCE as an independent variable is quite commonsensical with logic that the market appraises the bank on the basis of its long -term profitability and ROCE is the best presented long-term profitability measures.

Return on Net worth (RONW): The tern net worth is used to for the sum of share capital and reserve and surpluses, i.e. the owners' equity. The term is misleading. It connotes the erroneous meaning that owners; equity is "worth" something. The term net worth implies market, or real value, while owners; in the balance sheet recorded at book value. This term is a measure of profitability of a bank. It is calculation is arrived at using following formula:

$$
\text { RONW }=\quad \frac{\text { Profit after Taxes }(\text { Net of Non }- \text { recurring Items })}{\text { Average Net worth }} \times 100
$$

Earnings per Share (EPS): It is generally believed that earning per share have an effect on the hare price and consequently on Market Value Added (MVA). This is defined as:

$$
\text { EPS }=\frac{\text { Profit after Taxes- Dividend on Preference Shares }}{\text { Number of outstanding Equity Shares }} \times 100
$$

Return on Investment (ROI): The term investment may refer to total assets or net assets. The fund employed in net assets is known as capital employed. Net assets equal to net fixed assets plus current assets minus current liabilities excluding loans. Alternatively, capital employed is equal to net worth plus total debt.

The conventional approach of calculating return on investment (ROI) is to divide PAT by investment. Investment represents pool of funds supplied by share holder and lenders, while PAT represents residual income of shareholders; therefore, it is conceptually unsound to use PAT in the calculation of ROI. It is therefore, more appropriate to use following measure of ROI for comparing the operational efficiency of banks:

$$
\text { ROI }=\quad \frac{\text { Profit before Intrest and Tax es } \times(1-\text { Tax Rate })}{\text { Total Assets }} \times 100
$$

Profit after Taxes (PAT): Profit after Taxes (PAT) also called net income or earnings is an accounting concept can be defined as the amount a business earns after subtracting all expenses necessary from its revenue for particular financial year. To put it in equation from:

Profit after Taxes $(\mathrm{PAT})=$ Revenue - Expenses. 


\section{Database And Sources}

The data use to calculate NOPAT, Invested Capital, ROCE, ROWN, PAT, EPS and ROI etc. have yearly frequency i.e. collected from $1^{\text {st }}$ April to the $31^{\text {st }}$ March of fourteen financial years i.e. 2000-2013. The data used to calculate beta having daily frequency. Most of the data has been collected through various sites of internet, publications of National Stock Exchange of India, Bombay Stock Exchange, Reserve Bank of India, and most worthy 'PROWESS' database of Centre for monitoring Indian Economy (CMIE).

\section{Tools Of Analysis}

The Karl Pearson's Product-moment formula has been applied to determine relationship of EVA and other traditional financial performance measures. Karl Pearson's correlation coefficient provides us with the measure of linear relationship between any two variables

However, the correlation coefficients based on time series data are valid only under the assumption of non autocorrelation and stationarity.

To test whether the financial variables under study are stationary, a unit root test is performed using the Augmented Dickey-Fuller (ADF) methods. The Dickey-Fuller test has been applied to regressions run in the following four forms:

$$
\begin{array}{lll}
\text { I } & \Delta Y_{t}=\delta Y_{t_{1}}+\mu_{t} & 7 \\
\text { II } & \Delta Y_{t}=\beta_{1}+\delta Y_{t 1}+\mu_{t} & 8 \\
\text { III } & \Delta Y_{t}=\beta_{1}+\beta_{2}+\delta Y_{t_{1}}+\mu_{t} & 9 \\
\text { IV } & \Delta Y_{\varepsilon}=\beta_{1}+\beta_{2}+\delta Y_{t_{1}}+\alpha_{i_{i=1}}^{m_{i=1}} \Delta Y_{t_{1}}+\mu_{t} & 10
\end{array}
$$

Where, $\mathrm{Y}_{\mathrm{t}}=\mathrm{In}\left(\mathrm{P}_{\mathrm{t}}\right)$ is the natural logarithm of the value of each variable at time $\mathrm{t}, \Delta$ is the difference operator, and $t$ is for time.

In each model, the null hypothesis is that $\delta=0$, that is, there is a unit root. The difference of model $1^{\text {st }}$ from the $2^{\text {nd }}$ and $3^{\text {rd }}$ regressions lies in the inclusion of the constant (intercept: drift) and the trend term (Dickey-Fuller, 1979). If the error term $\mu_{\mathrm{t}}$ is auto correlated, the $3 \mathrm{rd}$ model is modified and taken as model-IV. When the DF test statistic is applied to models like (IV), it is called Augmented Dickey-Fuller (ADF) test. Each of the above models has also been applied to pooled data series for each variable. The ADF test statistic has the same asymptotic distribution as the DF statistic, so the same critical values are used.

It was examined whether the informational content of EVA is greater than that of traditional financial performance measures, Multiple Regression Model is applied. To avoid the problem of multi-Collinearity the following step-wise multiple regression equation is used:

$$
Y=a+b_{1} x_{1}+b_{2} x_{2}+b_{2} x_{3}+b_{4} x_{4}+b_{5} x_{5}+b_{6} x_{6}+\mu-\ldots-11
$$

Where, $\mathrm{Y}=$ Market value Added, $\mathrm{a}=$ constant term, $\mathrm{b}_{1}$ to $\mathrm{b}_{5}$ are the regression coefficients for the respective variables, $x_{1}=$ Economic Value Added (EVA), $x_{2}=$ ROCE, $x_{3}=$ ROWN, $x_{4}=$ EPS, $x_{5}=$ ROI, $x_{6}=$ PAT, and $\mu=$ error term. Here Y (i.e. Market Value Added) is the dependent variable, while the rest $\mathrm{x}_{1}$ to $\mathrm{x}_{6}$ are independent variables.

At first, ANOVA was calculated to conduct F-test so as to examine whether there exists a linear relationship between the dependent variable (Market Value Added) and any of the independent variables under consideration. Further $\mathrm{R}^{2}$ and adjusted $\mathrm{R}^{2}$ values were measured. Durbin and Watson (D-W) Test has also been applied to check the presence of auto-correlation in the time series data. The significance of the regression coefficients pertaining to various independent variables has been examined by applying t-test at $1 \%, 5 \%$ and $10 \%$ level of significance.

The study have also been considering a relatively simple test of causality, that proposed by Granger (1969). This test assumes that the information relevant to the prediction of the respective variables is contained solely in the time series data on these variables. The intuition behind the Granger causality test is quite straight forward. Suppose X variable causes $\mathrm{Y}$ but $\mathrm{Y}$ does not Granger cause $\mathrm{X}$, then past values of $\mathrm{X}$ should be able to predict future values of $Y$, but past values of $Y$ should not be helpful in forecast of $X$. Consider the following model in which $\mathrm{X}$ and $\mathrm{Y}$ are expressed as deviation of respective means.

$$
\begin{gathered}
Y_{t}=\sum_{i=1}^{n} \alpha_{i} X_{t} 1+\sum_{j=1}^{n} \beta_{i} Y_{t 1}+\mu_{1 t} \\
X_{t}=\sum_{i=1}^{n} \lambda_{i} Y_{t} i+\sum_{j=1}^{m} \delta_{i} X_{t 1}+\mu_{2 t}
\end{gathered}
$$


Where, it is assumed that the disturbances $\mu_{1 \mathrm{t}}$ and $\mu_{2 \mathrm{t}}$ are uncorrelated. The null hypothesis is $\mathrm{H}_{0}: \sum \alpha_{\mathrm{i}}=0$, that is, lagged $\mathrm{X}$ terms do not belong in the regression. To test this hypothesis, the $\mathrm{F}$ test is applied with $\mathrm{m}$ and $(\mathrm{n}-$ k) degrees of freedom. The null hypothesis is rejected when the lagged $X$ terms belong in the regression. This is another way of saying that X causes Y. Similarly, it can test the model (13), that is, whether Y causes X.

The hypothesis also tested by comparing $\mathrm{R}^{2}$ of the pooled regression with independent variables, each of the financial measures under examination. In order to conduct a formal test of both a relative and an incremental information content approach to examine which performance measure best explains market value of banks; and the explanatory power of the pair-wise combinations of one value-based performance measurement model and one traditional accounting performance measure in explaining market value. For this purpose, pooled timeseries, cross-sectional data of select banks has been modeled.

\section{Results And Discussion}

After satisfying the assumption of normally Table-2 put forward descriptive statistic of sample banks. The descriptive statistic so presented in the table is calculated using pooled cross-sectional data of 37 sample banks from 2000 to 2013. It can be seen that MVA value of the sample banks are ranging from 0.415 to 5.035 with an average of 3.001. Similarly EVA values are ranging from 0.098 to 4.193 with an average of 2.835, EPS vary from -1.187 to 6.770 with an average of 2.729 , PAT ranging from 0.928 to 9.118 with an average of 5.014, ROCE vary from -7.660 to 27.940 with an average of 9.053 , ROI vary from 0.196 to 1.128 with an average of 0.707 and RONW vary from -26.600 to 45.480 with an average of 16.074 . The standard deviation present in the table depicts variability among select variables from average. The Skewness and Kurtosis result leads to normality of the study variables.

Table No. - 2 Descriptive Statistics of Sample Banks

\begin{tabular}{|l|c|c|c|c|c|c|c|}
\hline \multicolumn{1}{|c|}{ Statistics } & MVA & EVA & EPS & PAT & ROCE & ROI & RONW \\
\hline Mean & 3.001 & 2.835 & 2.729 & 5.014 & 9.503 & 0.707 & 16.074 \\
\hline Std. Deviation & 0.808 & 0.586 & 1.443 & 1.512 & 6.273 & 0.129 & 8.775 \\
\hline Variance & 0.653 & 0.344 & 2.083 & 2.285 & 39.351 & 0.017 & 76.995 \\
\hline Skewness & -0.190 & -0.382 & 0.141 & -0.087 & 0.161 & 0.086 & -0.521 \\
\hline Kurtosis & -0.139 & 0.974 & 0.542 & -0.286 & -0.297 & 0.591 & 1.972 \\
\hline Minimum & 0.415 & 0.098 & -1.897 & 0.928 & -7.660 & 0.196 & -26.600 \\
\hline Maximum & 5.035 & 4.193 & 6.770 & 9.118 & 27.940 & 1.128 & 45.480 \\
\hline Range & 4.620 & 4.095 & 8.667 & 8.190 & 35.600 & 0.932 & 72.080 \\
\hline N & 372 & 487 & 455 & 488 & 493 & 504 & 493 \\
\hline
\end{tabular}

Table No. 3 Augmented-D F Unit Root Test Select on Variables of Sample Banks

\begin{tabular}{|c|c|c|c|c|c|c|}
\hline \multirow[t]{2}{*}{ Equation } & \multicolumn{3}{|c|}{$\begin{array}{c}\text { D.F Statistic at level } \\
\operatorname{In}\left(\mathbf{P}_{\mathfrak{t}}\right)\end{array}$} & \multicolumn{3}{|c|}{$\begin{array}{c}\text { Unit Root of D.F Statistics at } \\
1^{\text {st }} \text { Difference } \\
\mathbf{R}_{t}=\operatorname{In}\left(\mathbf{P}_{t}\right)-\operatorname{In}\left(\mathbf{P}_{t-1}\right)\end{array}$} \\
\hline & $\begin{array}{c}\text { t-value } \\
\text { (D.F) }\end{array}$ & $\tau$ & $\begin{array}{l}\text { Durbin } \\
\text { Watson }\end{array}$ & $\begin{array}{c}\text { t-value } \\
\text { (D.F) }\end{array}$ & $\tau$ & $\begin{array}{l}\text { Durbin } \\
\text { Watson }\end{array}$ \\
\hline \multicolumn{7}{|l|}{ EVA (1) } \\
\hline H0: Unit Root without drift & -1.021 & -1.940 & 2.054 & -17.056 & -2.570 & 1.995 \\
\hline H0: Unit root with drift & -7.203 & -3.446 & 2.026 & -17.037 & -3.440 & 1.995 \\
\hline H0: Unit root with drift and trend & -7.252 & -3.982 & 2.027 & -17.021 & -3.982 & 1.999 \\
\hline \multicolumn{7}{|l|}{ MVA (1) } \\
\hline H0: Unit Root without drift & 2.900 & -2.572 & 2.122 & -9.704 & -2.573 & 2.038 \\
\hline H0: Unit root with drift & -3.065 & -3.454 & 2.138 & -10.204 & -3.455 & 1.984 \\
\hline H0: Unit root with drift and trend & -3.079 & -3.991 & 2.137 & -10.185 & -3.995 & 1.984 \\
\hline \multicolumn{7}{|l|}{ PAT (1) } \\
\hline H0: Unit Root without drift & -1.368 & -2.571 & 2.068 & -18.060 & -2.570 & 2.035 \\
\hline H0: Unit root with drift & -7.980 & -3.447 & 2.015 & -18.039 & -3.447 & 2.035 \\
\hline H0: Unit root with drift and trend & -7.213 & -3.982 & 2.017 & -18.045 & -3.983 & 2.036 \\
\hline \multicolumn{7}{|l|}{ EPS (1) } \\
\hline H0: Unit Root without drift & -1.683 & -2.570 & 2.072 & -16.057 & -2.571 & 2.041 \\
\hline H0: Unit root with drift & -6.286 & -3.448 & 2.037 & -16.073 & -3.449 & 2.040 \\
\hline H0: Unit root with drift and trend & -6.711 & -3.984 & 2.039 & -16.049 & -3.985 & 2.040 \\
\hline \multicolumn{7}{|l|}{ ROI (1) } \\
\hline H0: Unit Root without drift & -1.793 & -2.570 & 2.038 & -20.109 & -2.570 & 2.024 \\
\hline H0: Unit root with drift & -10.00 & -3.446 & 1.962 & -20.099 & -3.446 & 2.024 \\
\hline H0: Unit root with drift and trend & -9.993 & -.3 .981 & 1.962 & -20.071 & -3.981 & 2.024 \\
\hline
\end{tabular}


Indian Banking and Information Content of EVA and Traditional Measures

\begin{tabular}{|l|l|l|l||l|l|l|l|}
\hline ROCE (1) \\
\hline H0: Unit Root without drift & -4.741 & -2.571 & 2.076 & -20.449 & -2.570 & 2.026 \\
\hline H0: Unit root with drift & -10.56 & -3.446 & 2.008 & -20.424 & -3.447 & 2.026 \\
\hline H0: Unit root with drift and trend & -10.58 & -3.981 & 2.008 & -20.409 & -3.982 & 2.026 \\
\hline RONW (1) & -4.163 & -2.570 & 2.032 & -19.913 & -2.570 & 2.022 \\
\hline H0: Unit Root without drift & -11.74 & -3.447 & 2.013 & -19.888 & -3.447 & 2.022 \\
\hline H0: Unit root with drift & -1174 & -3.981 & 2.015 & -19.893 & -3.982 & 2.022 \\
\hline H0: Unit root with drift and trend &
\end{tabular}

Table-3 presented Augmented Dickey-Fuller unit root test of stationarity on selected variables of the study. Dickey-Fuller has shown under null hypothesis the $\delta=0$, the estimated t-value of the co-efficient in equation-7 follows the $\tau$-(tau) statistics (Dickey D.A. et. al., 1979). In the literature the tau statistics or tests is known as Dickey-Fuller test. If the null hypothesis is rejected, it means that $\mathrm{V}_{\mathrm{t}}$ is a stationary time series with zero mean is case of equation 7 , that $Y_{t}$ is stationary with a non-zero mean $\left[=\beta_{i}(1-p)\right]$ in the case of equation 8 and, and that $Y_{1}$ is stationary ground, deterministic trend in equation 9 (Dickey at. el, 1979).

Table-3 presented result of DF-Test at level $\left(P_{t}\right)$ and unit root of D.F. statistics at $1^{\text {st }}$ difference $\left[R_{t}=1 n\right.$ (Pt) -In $\left.\left(\mathrm{P}_{\mathrm{t}}-1\right)\right]$ without drift (trend), with drift, and with drift and trends on respective study variables. In simple words if the $\tau$ (tau)-value is more than $\mathrm{t}-$ value null hypothesis is rejected means that time series (variable) is a stationary. Table shows that EVA accepting the null hypothesis at level with -1.940 tau value and $-1.021 \mathrm{t}-$ values but it rejects the null hypothesis at $1^{\text {st }}$ difference in all the cases. However, EVA data (pooled) is stationary. Likewise, MVA, PAT, EPS, ROI, ROCE, and RONW all the variable rejecting null hypothesis of non-stationarity at level or at $1^{\text {st }}$ difference. Thus, the first difference of random-walk variables is stationarity for all variables under study.

\section{Empirical Examination of Select Sample Banks}

Table-4 presents correlation matrix among independent select financial variables of sample banks. Each variable is perfectly correlating itself having ' $r$ ' equal to 1 along with the diagonal of the matrix. In each cell of the matrix table presented Karl Pearson's correlation coefficient ( $r$ ), p-value for two-tailed test of significance, and the sample size. Table reveals that correlation coefficient between Profits after Taxes (PAT) and Economic Value Added (EVA) is 0.895 and p-value is less than one percent. Correlation Coefficient between ROCE and RONW is 0.723 , which is significant at one percent. However, association between ROCE and RONW is strong and positive mean that variables having movement in some direction. Where the direction of association between rests of financial variable is low.

Table No. 4 Karl Pearson's Correlation Coefficients among Individual Variables of Sample Banks

\begin{tabular}{|c|c|c|c|c|c|c|c|}
\hline & & EVA & EPS & PAT & ROCE & ROI & RONW \\
\hline \multirow[b]{2}{*}{ EVA } & \multirow{2}{*}{$\begin{array}{c}\mathbf{r} \\
\text { p-value (2-tailed) } \\
\mathbf{N} \\
\end{array}$} & \multirow[b]{2}{*}{1} & & & & & \\
\hline & & & & & & & \\
\hline \multirow{2}{*}{ EPS } & \multirow{2}{*}{$\begin{array}{c}\mathbf{r} \\
\mathbf{p} \text {-value (2-tailed) } \\
\mathbf{N} \\
\end{array}$} & $0.300 * *$ & \multirow[b]{2}{*}{1} & & & & \\
\hline & & $\begin{array}{c}0.000 \\
440 \\
\end{array}$ & & & & & \\
\hline \multirow[b]{2}{*}{ PAT } & \multirow{2}{*}{$\begin{array}{c}\mathbf{r} \\
\text { p-value (2-tailed) } \\
\mathbf{N} \\
\end{array}$} & $0.895^{*}$ & $0.389 *$ & \multirow[b]{2}{*}{1} & & & \\
\hline & & $\begin{array}{c}0.000 \\
473\end{array}$ & $\begin{array}{c}0.000 \\
450\end{array}$ & & & & \\
\hline \multirow{3}{*}{ ROCE } & \multirow{3}{*}{$\begin{array}{c}\mathbf{r} \\
\text { p-value (2-tailed) } \\
\mathbf{N} \\
\end{array}$} & 0.019 & $0.234 *$ & $0.159^{*}$ & 1 & & \\
\hline & & 0.675 & 0.000 & 0.000 & & & \\
\hline & & 478 & 450 & 485 & & & \\
\hline \multirow[b]{2}{*}{ ROI } & \multirow{2}{*}{$\begin{array}{c}\mathbf{r} \\
\text { p-value (2-tailed) } \\
\mathbf{N}\end{array}$} & $-0.183^{*}$ & $-0.123^{*}$ & $-0.299^{*}$ & 0.073 & 1 & \\
\hline & & $\begin{array}{c}0.000 \\
487\end{array}$ & $\begin{array}{c}0.009 \\
453\end{array}$ & $\begin{array}{c}0.000 \\
487\end{array}$ & $\begin{array}{c}0.105 \\
492\end{array}$ & & \\
\hline \multirow{3}{*}{ RONW } & \multirow{3}{*}{$\begin{array}{c}\mathbf{r} \\
\text { p-value (2-tailed) } \\
\mathbf{N} \\
\end{array}$} & 0.079 & $0.394 *$ & $0.248^{*}$ & $0.723^{*}$ & $0.143 *$ & 1 \\
\hline & & 0.084 & 0.000 & 0.000 & 0.000 & 0.002 & \\
\hline & & 478 & 450 & 485 & 490 & 492 & \\
\hline
\end{tabular}

* Correlation is significant at the 0.01 level (2-tailed).

** Correlation is significant at the 0.05 level (2-tailed).

Table - 5 provides Karl Pearson's (r) Zero order correlation matrix of sample banks. Underneath each correlation coefficient $(\mathrm{r})$ both the significant value of correlation and sample size $(\mathrm{N})$ on which it is based are presented. It can be seen that correlation between select financial variable and market value added (MVA) is either very low or moderately high. Profit after Taxes (PAT) is positively relates to the market value added having coefficient (r) 0.824 with less than one percent probability, this big would have not occurred by chance 
in the sample of 361 observations. The significant values depicts in the table that the probability of MVA and PAT correlation being a 'fluke' is very low (close to Zero in fact). Hence, the relationship between PAT and MVA is very high. EVA also reported positive correlation coefficient 0.758 which is also significant at one percent. EPS has also exhibits positive significant (one percent) correlation with MVA. But ROI and ROCE portrayed negative relationship with MVA with a correlation coefficient -0.254 and -0.152 respectively which is also significant at less than one percent.

Table No. 5 Karl Pearson's Zero Order Correlation Matrix of Sample Banks

\begin{tabular}{|c|c|c|c|c|c|c|c|}
\hline & & EVA & EPS & PAT & ROCE & ROI & RONW \\
\hline & $\mathbf{r}$ & $\mathbf{0 . 7 5 8} * *$ & $\mathbf{0 . 1 8 8} * *$ & $\mathbf{0 . 8 2 4} * *$ & $\mathbf{- 0 . 1 5 2} * *$ & $\mathbf{- 0 . 2 5 4} * *$ & 0.002 \\
MVA & $\mathbf{p}$-value (2-tailed) & $\mathbf{0 . 0 0 0}$ & $\mathbf{0 . 0 0 0}$ & $\mathbf{0 . 0 0 0}$ & $\mathbf{0 . 0 0 4}$ & $\mathbf{0 . 0 0 0}$ & 0.964 \\
& $\mathbf{N}$ & 358 & 364 & 361 & 363 & 369 & 364 \\
\hline
\end{tabular}

** Correlation is significant at the 0.01 level (2-tailed).

* Correlation is significant at the 0.05 level (2-tailed).

So on account of movement of MVA, ROI and ROCE move in opposite direction. However, profit after taxes, Economic Value Added, return on investment and earnings per share are having significant positive relation with market value added during study period.

Table No. 6 Regression Model with Market Value Added for the Sample Banks valuation Variables, Pooled Time-Series Cross-Sectional Data

\begin{tabular}{|c|c|c|c|c|c|c|c|c|}
\hline Constant & PAT & EVA & ROCE & RONW & EPS & ROI & F-Ratio & $\mathbf{R}^{2}$ (Adjusted) \\
\hline $\begin{array}{l}* 0.573 \\
(0.092)\end{array}$ & $\begin{array}{c}* 0.455 \\
(0.017)\end{array}$ & & & & & & 756.59 & 0.667 \\
\hline $\begin{array}{l}-0.181 \\
(0.148)\end{array}$ & & $\begin{array}{l}* 1.086 \\
(0.049)\end{array}$ & & & & & 481.16 & 0.574 \\
\hline $\begin{array}{l}* 3.196 \\
(0.076)\end{array}$ & & & $\begin{array}{l}*_{-0.019} \\
(0.007)\end{array}$ & & & & 8.55 & 0.020 \\
\hline $\begin{array}{l}* 3.004 \\
(0.090)\end{array}$ & & & & $\begin{array}{l}* 0.001 \\
(0.005)\end{array}$ & & & 0.002 & 0.001 \\
\hline $\begin{array}{l}* 2.717 \\
(0.093)\end{array}$ & & & & & $\begin{array}{l}* 0.107 \\
(0.029)\end{array}$ & & 13.28 & 0.033 \\
\hline $\begin{array}{l}* 4.100 \\
(0.233)\end{array}$ & & & & & & $\begin{array}{c}*-1.625 \\
(0.323)\end{array}$ & 25.40 & 0.062 \\
\hline $\begin{array}{l}* 0.578 \\
(0.153)\end{array}$ & $\begin{array}{c}* 0.463 \\
(0.046)\end{array}$ & $\begin{array}{c}-0.017 \\
(0.120)\end{array}$ & & & & & 357.45 & 0.671 \\
\hline $\begin{array}{l}* 0.810 \\
(0.086)\end{array}$ & $\begin{array}{l}* 0.471 \\
(0.015)\end{array}$ & & $\begin{array}{l}*_{-0.033} \\
(0.003)\end{array}$ & & & & 534.94 & 0.741 \\
\hline $\begin{array}{l}* 0.820 \\
(0.084)\end{array}$ & $\begin{array}{l}* 0.500 \\
(0.051)\end{array}$ & & & $\begin{array}{c}-* 0.029 \\
(0.003)\end{array}$ & & & 544.86 & 0.752 \\
\hline $\begin{array}{l}* 0.638 \\
(0.090)\end{array}$ & $\begin{array}{l}* 0.495 \\
(0.018)\end{array}$ & & & & $\begin{array}{l}*_{-0.098} \\
(0.018)\end{array}$ & & 420.16 & 0.700 \\
\hline $\begin{array}{l}* 1.272 \\
(0.166)\end{array}$ & $\begin{array}{l}* 0.443 \\
(0.016)\end{array}$ & & & & & $\begin{array}{c}*_{-0} 0.932 \\
(0.187)\end{array}$ & 415.71 & 0.697 \\
\hline $\begin{array}{c}0.020 \\
(0.152)\end{array}$ & & $\begin{array}{l}* 1.083 \\
(0.048)\end{array}$ & $\begin{array}{l}*_{-0} 0.019 \\
(0.004)\end{array}$ & & & & 262.32 & 0.597 \\
\hline $\begin{array}{l}-0.059 \\
(0.147)\end{array}$ & & $\begin{array}{l}* 1.116 \\
(0.049)\end{array}$ & & $\begin{array}{l}*_{-} 0.013 \\
(0.003)\end{array}$ & & & 260.78 & 0.595 \\
\hline $\begin{array}{l}-0.177 \\
(0.149)\end{array}$ & & $\begin{array}{l}* 1.124 \\
(0.053)\end{array}$ & & & $\begin{array}{c}* *_{*}-0.039 \\
(0.021)\end{array}$ & & 242.65 & 0.579 \\
\hline $\begin{array}{l}* 1.006 \\
(0.204)\end{array}$ & & $\begin{array}{c}* 1.075 \\
(0.046)\end{array}$ & & & & $\begin{array}{c}*-1.713 \\
(0.219)\end{array}$ & 311.90 & 0.635 \\
\hline $\begin{array}{l}* 3.038 \\
(0.092)\end{array}$ & & & $\begin{array}{l}*_{-} 0.040 \\
(0.010)\end{array}$ & $\begin{array}{l}* 0.022 \\
(0.008)\end{array}$ & & & 8.30 & 0.039 \\
\hline $\begin{array}{l}* 2.860 \\
(0.101)\end{array}$ & & & $\begin{array}{l}*_{-} 0.029 \\
(0.007)\end{array}$ & & $\begin{array}{c}0.151 \\
(0.030) \\
\end{array}$ & & 17.57 & 0.089 \\
\hline $\begin{array}{l}* 4.374 \\
(0.228)\end{array}$ & & & $\begin{array}{l}*_{-} 0.017 \\
(0.006)\end{array}$ & & & $\begin{array}{l}-1.769 \\
(0.324)\end{array}$ & 19.55 & 0.093 \\
\hline $\begin{array}{l}* 2.792 \\
(0.108)\end{array}$ & & & & $\begin{array}{c}*_{*} *_{-0.032} \\
(0.005)\end{array}$ & $\begin{array}{l}* 0.246 \\
(0.032)\end{array}$ & & 10.43 & 0.050 \\
\hline $\begin{array}{l}* 4.081 \\
(0.228)\end{array}$ & & & & $\begin{array}{c}0.003 \\
(0.005)\end{array}$ & & $\begin{array}{c}*_{-1} .661 \\
(0.324)\end{array}$ & 13.12 & 0.065 \\
\hline $\begin{array}{l}* 3.818 \\
(0.241)\end{array}$ & & & & & $\begin{array}{l}* 0.107 \\
(0.029)\end{array}$ & $\begin{array}{c}*_{-1} 1.624 \\
(0.318)\end{array}$ & 21.49 & 0.102 \\
\hline $\begin{array}{l}* 1.688 \\
(0.170)\end{array}$ & $\begin{array}{c}* 0.620 \\
(0.045)\end{array}$ & $\begin{array}{l}*_{-0321} \\
(0.111)\end{array}$ & $\begin{array}{l}*_{-} 0.017 \\
(0.005)\end{array}$ & $\begin{array}{l}*_{-} 0.017 \\
(0.004)\end{array}$ & $\begin{array}{l}*_{-0.054} \\
(0.014)\end{array}$ & $\begin{array}{l}*_{-} 0.671 \\
(0.014)\end{array}$ & 203.88 & 0.777 \\
\hline
\end{tabular}


To gain further insights Table-6 carries out a pooled cross-sectional regression analysis over the period 20002013 for select sample banks. According to Fama and French (1997) the advantages of the cross-sectional analysis is that it takes into account a large sample which, well increase the precision of the slope and reduce the year by year volatility. The additional advantage of cross-sectional analysis in the context of the period under reference for the present study is its appropriateness and ability to bring out the behavior of MVA, and relative information of contents of exploratory variables which correlate maximally with the predictor (MVA). To avoid the problem of multicollinearity step-wise multiple regression models was applied. Biddle's et. al. (1997), Bao and Bao (1998), made comparisons using approach selected in the present section. Table-6 presents the estimated beta $\left(\beta_{\mathrm{i}}\right)$ coefficients and standard errors (in brackets) of banks regression are from equation- 11 . The table depicts that all six financial performance measures are significantly associated with market value added over the period 2000-2013. Out of forty two estimated slops, thirty eight are significant at one percent level, and only two are significant at 5 and 10 percent respectively, and rest of four are not in predicted direction. The estimated coefficients of determination $\left(\mathrm{R}^{2}\right)$ in the table depicts that earning (PAT) and other accounting measures are positively associated with the market value added (MVA) over last fourteen years. The estimated slope $\left(\beta_{\mathrm{i}}\right)$ coefficients are significant at one percent. However, these results hold even when pair wise grouping of performance measures are exacted from the same regression. The summary results of these regressions in the form of relative and informational contents tests are presented in Table- 7 and 8.

Table No. 7 Relative Informational Contents of the Sample Banks valuation Variables, Pooled Time-Series Cross-Sectional Data

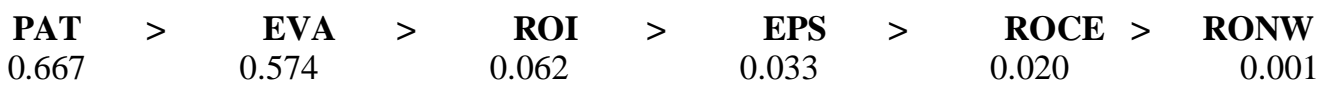

Table-7 presented that there is significant difference in relative information contents of predictors. The highest coefficient of determination $\left(\mathrm{R}^{2}\right)$ from the single regression is shown on the left; with lower explanatory power is descending order to right. The findings is that PAT having highest relative explanatory (66.7 percent) power do explain market value added as compared to EVA, ROI, EPS, ROCE alone. Biddle's et. al. (1999) results also presents same indication that, earnings (EBEI), has the highest adjusted $\mathrm{R}^{2}$ and EVA has smaller adjusted $\mathrm{R}^{2}$ that these results do not support the hypothesis that EVA dominates traditional performance measure in its association with stock market return. The table presents that the relative informational content of EVA is lower than PAT, which, accounting for only 57.4 present of variation in market value added (MVA).

Table No. 12 Incremental Informational Contents of the Sample Banks valuation Variables, Pooled Time-Series Cross-Sectional Data

\begin{tabular}{|c|c|c|c|c|c|}
\hline EVA/PAT & PAT/EVA & EVA/ROI & ROI/EVA & EVA/EPS & EPS/EVA \\
\hline 0.004 & 0.097 & 0.573 & 0.061 & 0.546 & 0.005 \\
\hline EVA/ROCE & ROCE/EVA & EVA/RONW & RONW/EVA & PAT/ROI & PAT/ROI \\
\hline 0.577 & 0.023 & 0.594 & 0.021 & 0.635 & 0.635 \\
\hline PAT/EPS & EPS/PAT & PAT/ROCE & ROCE/PAT & PAT/RONW & PAT/RONW \\
\hline 0.667 & 0.033 & 0.721 & 0.074 & 0.751 & 0.751 \\
\hline ROCE/RONW & RONW/ROCE & ROCE/EPS & EPS/ROCE & ROCE/ROI & ROCE/ROI \\
\hline 0.038 & 0.019 & 0.056 & 0.069 & 0.031 & 0.031 \\
\hline RONW/EPS & EPS/RONW & RONW/ROI & ROI/RONW & EPS/ROI & EPS/ROI \\
\hline 0.017 & 0.049 & 0.003 & 0.064 & 0.050 & 0.050 \\
\hline
\end{tabular}

The explanatory power of traditional financial performance measures is significantly high as compared to EVA than that found in a number of similar studies. For example, Peixoto (2002) reported that the net income variable has a higher informational content than EVA and operating profits, when the dependent variable is the market value of the companies. Kim (2006), conclude the results of the study do not support the claim that EVA is better financial tool than traditional accounting measurements in explaining market value. EVA did not significantly outperform traditional accounting measures in the test of relative information contents. Biddle's et. al. (1997) estimated the relative information content of EBEI, R1, EVA and NCF at 9.04, 6.24, 5.07 and 2.38 percent respectively. Similarly, Ismail (2006), agrees that net operating profit after tax and net income outperform EVA and residual income in explaining stock return 
The findings in the Table- 8 also based on equation- 11 and provide incremental information content test for the pair wise regression model of PAT, EVA, ROI, EPS, ROCE, and RONW e.g. EVA/PAT (0.4 percent) is equal to information content of pair wise compression of EVA, PAT (67.1 percent) minus the information content of PAT (66.7 percent). The pair wise regression model of EVA, PAT, ROI, EPS, ROCE, and RONW indicates that the explanatory power has increased by $0.097,0.061,0.005,0.023$, and 0.021 respectively over the EVA measure alone. Bao and Bao (1998) analyzed the pooled date indicates that earning has a zero impact on EVA alone, while residual income increases explanatory power by some 38 percent. However, the results of present analysis depict that PAT has largest relative information content along the measure with EVA (0.004), ROI (0.030), EPS (0.033), ROCE (0.074) and RONW (0.084) providing only partial incremental information content away from earnings. The most rational combination of information variables in explaining market return is therefore of PAT and ROCE.

Table No. 9 Granger Causality Test on Pooled Data of Sample Banks

\begin{tabular}{|l|c|c|c|}
\hline \multicolumn{1}{|c|}{ Null Hypothesis: } & Observations & F-Statistic & p-value \\
\hline EVA does not Granger Cause MVA & 160 & 2.25070 & 0.04158 \\
MVA does not Granger Cause EVA & & $2.54401^{*}$ & 0.02257 \\
\hline EPS does not Granger Cause MVA & 159 & 1.43209 & 0.52373 \\
MVA does not Granger Cause EPS & & 1.88205 & 0.20614 \\
\hline PAT does not Granger Cause MVA & 156 & $2.28348^{*}$ & 0.08779 \\
MVA does not Granger Cause PAT & & $2.71318^{*}$ & 0.03902 \\
\hline ROCE does not Granger Cause MVA & 159 & 3.52064 & 0.17526 \\
MVA does not Granger Cause ROCE & & 1.63307 & 0.00138 \\
\hline ROI does not Granger Cause MVA & 180 & $5.10047 *$ & 0.14090 \\
MVA does not Granger Cause ROI & & 0.43669 & 0.00081 \\
\hline RONW does not Granger Cause MVA & 172 & 0.85349 \\
MVA does not Granger Cause RONW & & & \\
\hline
\end{tabular}

To gain further insight Table-9 put forward the results of Granger Causality Test. The multiple regression analysis deals the dependence of one variable or other variables, it does not necessary imply causation. In other words it does not prove the direction of influence. Here an attempt has been made to test the hypothesis $\left(\mathrm{H}_{003}\right)$ that Economic Value Added (EVA) and other select traditional financial variable does not Granger cause Market Value Added and vice-a-versa. The table presents the Null Hypothesis in pair vis-à-vis market value added, and respective F-statistic with p-value. Economic value added does not cause (Granger) MVA accept the hypothesis have F-value 2.250 which is insignificant at 5 percent level, on the other hand that the hypothesis MVA does not cause EVA is rejected having significant $2.554 \mathrm{~F}$-value at 5 percent level of significance. Thus, EVA lead to MVA through study period, while the causal relationship between EPS $\rightarrow$ MVA, and MVA $\rightarrow$ EPS accept both the hypothesis having in significant F-statistics. The casual relation between $\mathrm{PAT} \rightarrow \mathrm{MVA}$, and MVA $\rightarrow$ PAT, reject the first hypothesis and accept the second one, means that profit after taxes lead to MVA. About the casual relation between ROCE $\rightarrow$ MVA and MVA $\rightarrow$ ROCE reject the first, and accept the second in pair hypothesis. The directional influence assumption between ROI $\rightarrow$ MAV and MVA $\rightarrow$ ROI reject first one and accept the second hypothesis. The casual relation between RONW $\rightarrow$ MVA rejected and MVA $\rightarrow$ ROCE accepted on the parameters. However, PAT, EVA, ROI, RONW variables lead to market value added as supported by the forgone analysis in the present chapter

\section{Conclusion}

The review of literature regarding EVA has given assorted view. Accounting based performance measures such as net profit (PAT), earnings per share (EPS), return on equity (ROE), return on assets (ROA) and return on investment (ROIC) are among the most commonly used performance measures, they are often criticized for not taking into consideration the total cost of capital and for being unduly influenced by accrualbased accounting conventions. Profounder of EVA (Stewart, 1991) support that such traditional measures as earning per share (EPS), return on equity (ROE), and return on investment (ROI) are misleading measures of corporate performance. But the empirical evidences about superiority of EVA over traditional matrices are mixed and considering only manufacturing sector. So, the present section outlines concluding remarks.

Firstly, the stated hypothesis $\left(\mathrm{H}_{001}\right)$ of the study, that the select variables (MVA, EVA, PAT, EPS, ROCE, RONW, and ROI) are having asymmetrical distribution through the period under reference is rejected using Shapiro-Wilk W-statistic test of normality. Thus, all study variables through study period exhibits normality of distribution after applying transformation, and the first difference of random-walk variables is also stationarity for select variables of study.

Secondly, Karl Pearson's (r) Zero order correlation matrix of sample banks presents that association between select financial variable and market value added (MVA) is either low or moderately high. Profit after Taxes (PAT) is positively associated to the market value added having coefficient (r) 0.824 which is significant 
at one percent, EVA also reported positive (0.758) relationship with MVA but less than PAT. Further, on account of movement of MVA, ROI and ROCE move in opposite direction. However, profit after taxes, Economic Value Added, return on investment and earnings per share are having significant positive relation with market value added during study period

Thirdly, cross-section regression results on sample banks depict that coefficient of determination $\left(\mathrm{R}^{2}\right)$ ranges from 0.806 to 0.987 during last fourteen year. This is an indication of the significantly high explanatory power of the model. In other, words the emerged significant independent variables lead to more than 80 percent of variation in Market Value Added (MVA) of the sample banks. Profit after Taxes (PAT) emerged as a most significant predictor through the study period and forms a part of finally selected model through study period. The regression coefficients for EVA turn out to be negative at one percent level of significance. So, crosssection regression results reveal that earning (PAT) having highest explanatory power than EVA, ROI and EPS to explain market value added by sample banks. Further, Economic Value Added (EVA) and other select traditional financial variable does not Granger cause Market Value Added is rejected, and found that PAT, EVA, ROI, and RONW Granger cause, mean affecting the market value added as supported by the results of Granger Causality test.

Fourth, the relative and incremental informational test present that The PAT having highest relative explanatory (66.7 percent) power do explain market value added as compared to EVA, ROI, EPS, ROCE alone and the relative informational content of EVA is lower than PAT, which, accounting for only 57.4 present of variation in market value added (MVA). Thus, the explanatory power of traditional financial performance measures is significantly high as compared to EVA than that found in similar studies; Peixoto (2002) reported that the net income variable has a higher informational content than EVA and operating profits, when the dependent variable is the market value of the companies. Kim (2006), conclude the results of the study do not support the claim that EVA is better financial tool than traditional accounting measurements in explaining market value. EVA did not significantly outperform traditional accounting measures in the test of relative information contents. Biddle's et. al. (1997) estimated the relative information content of EBEI, R1, EVA and NCF at 9.04, 6.24, 5.07 and 2.38 percent respectively. Similarly, Ismail (2006) agrees that net operating profit after tax and net income outperform EVA and residual income in explaining stock return. The pair-wise incremental informational contents model as suggested by Biddle's et. al. (1997), Bao and Bao (1998), used to analysis, that EVA, PAT, ROI, EPS, ROCE, and RONW independent variables explanatory power has increased by $0.097,0.061,0.005,0.023$, and 0.021 respectively over the EVA measure alone. However, PAT has largest incremental information content along the measure, EVA (0.004), ROI (0.030), EPS (0.033), ROCE (0.074) and RONW (0.084) providing only partial incremental information content away from earnings. The most rational combination of information variables in explaining market return is therefore of PAT and ROCE. Bao and Bao (1998) study also find similar results that earning has a zero impact on

Though, the findings are consistent with several prior studies like of Dodd and Chen (1996 and 1997), Biddle's et. al. (1997), Bao and Bao (1998), Peixoto (2002), and Kim (2006) that PAT is highly correlated with market value added (MVA) and emerged as relatively better explanatory variable. Nevertheless as per the results Economic Valued Added (EVA) outperforms some of the traditional financial performance measures.

- The usefulness of EVA for decision making can't be ruled out based on the results and it can be used as an internal as well as external performance measurer. As Solomon (1965) suggested that residual income be used as an internal performance measure and Anthony (1973, 1982, and 1982) suggested that it is suitable to measure external performance.

- Secondly, the suppliers of capital (Market) may have failed to recognize the reporting benefits of EVA, as the results of the survey conclude that there is little awareness about the EVA among Indian Banking Industry. PAT and other traditional financial indicator information are readily available, and the market value is greatly influenced by publicly available information.

- Furthermore, the Indian banks may not be recognizing the EVA benefits or even investors also not considering EVA for the valuation of the stocks. So, it is suggested that banking industry will have to exploit the benefits of the EVA as an internal as well as external performance measurer along with disclosing EVA in their annual reports.

- The results also suggest that consolidation of banks provide synergy effect lead to generate higher economic value additions. So, the Indian banks will have to go for further possible consolidation because market reacts sharply by increasing capitalization, and the shareholders of banks may blessed by appreciable increase in their wealth.

- It is further sought that banks will have to invest more in technology and also be open to strategic alliances, restructuring for adding value to shareholders wealth for time to come. 


\section{References}

[1]. Abdeen, A. M., \& Haight, G. T. (2000). A Fresh Look at Economic Value Added: Empirical Study of the Fortune Five-Hundred Companies. The Journal of Applied Business Research, 18(2) 27-35.abstract_id=270799

[2]. Acheampong Y. J. \& Wetzstein M.E (2001). A Comparative Analysis of Value Added and Traditional Measures of Performance: An Efficiency Score Approach. Social Science Research Network Electronic Paper Collection, FS 01-04.

[3]. Anand, M., Garg, A., \& Arora, A. (1998). Economic Value Added: Business Performance Measure of Shareholder Value. The Management Accountant, May 1999, 351-356.

[4]. Andy Field (2004), "Discovering Statistics using SPSS for window" Sage publication, pp 143

[5]. Anthony, R. N. (1973). Accounting for Cost of Equity. Harvard Business Review, 51 (6), Nov/Dec 1973, 88-102.

[6]. Anthony, R. N. (1982). Equity Interest-its time has come. Journal of Accountancy, 154, December 1982, 76-93.

[7]. Anthony, R. N. (1982). Recognizing the Cost of Interest on Equity. Harvard Business Review, 61 (1), Jan/Feb 1982, $91-96$

[8]. Bacidore, J.M., Boquits, J.A., Milbourn, T.T., \& Thakor, A.V. (1997). The Search for the Best Financial Performance Measure. Financial Analysts Journal, May/June 1997, 11-20.

[9]. Banerjee, A. (1997). Economic Value Added: A Better Performance Measures. The Management Accountant, December 1997, 88688.

[10]. Banerjee, A. and Jain (1998). Economic Value Added and Shareholder Wealth: An Empirical Study of Relationship. Paradigm, 3(1), Jan- June 1999, 99-135.

[11]. Bao, B. H. \& Bao, D. H. (1999). The Association Between Firm Value and Economic Value Added. Indian Accounting Review, 3(2), December 1999, 161-164.

[12]. Bao, B. H., \& Bao, D. H. (1998). Usefulness of Value Added and Abnormal Economic Earnings: An Empirical Examination. Journal of Business Finance and Accounting, 25 (1-2), 251-265.

[13]. Biddle G.C., Bowen R.M., \& Wallace J. S. (1999). Evidence on EVA. Journal of Applied Corporate Finance, 12(2) 67-79.

[14]. Biddle, G. C. (1998). Economic Value Added: Some Empirical EVAdence. Managerial Finance, 24 (11), 60-70.

[15]. Biddle, G. C., Bowen G. S., \& Wallace, J.S. (1997). Does EVA Beat Earnings? Evidence on Associations with Stock Returns and Firm Values. Journal of Accounting and Economics, 24(3), 301-336.

[16]. Both, P. (1997). EVA As a Management Incentive. Management Accounting, April 1997, 48-50.

[17]. Buekette, G. D., \& Hedley, T. P. (1997). The Truth About Economic Value Added. The CPA Journal, July, 46-55.

[18]. Calabrese, V. J. (1999). Economic value Added: Finance 101 on steroids. Journal of Bank Cost and Management. Retrieved October 04, 2005, from Findarticles.com.

[19]. Chang, J. (1997). Spreading EVA. Chemical Market Reporter, July 14, 1997, $252(2), 3$.

[20]. Chen, S., \& Dodd, J. L. (1996). Economic Value Added (EVA): An Empirical Examination of a New Corporate Performance Measure. Journal of Managerial Issues, 9(3) 318-333.

[21]. Conley, P. (1995). Key Indicator Signals Peril for Rail, Say Consultant. Journal of Commerce and Management, April 17, 1995, 27(28454), 2.

[22]. Dickey, D. A., \& Fuller, W. A. (1979). Distribution of the Estimators for Autoregressive Time Series with a Unit Root," Journal of the American Statistical Association, 74, 427-431.

[23]. Dimitris, K. \& Christos, A. (2007).The Validity of the Economic Value Added Approach: an Empirical Application. European Financial Management, 13(1), January 2007, 71-100.

[24]. Dodd, J., Chen, S. (1997). EVA: A New Panacea. Business and Economic Review, 42, July- Sept, 1997, $26-28$.

[25]. Druker, P. F. (1995). The Information Executives Truly Need. Harward Business Review, Jan-Feb, 54-62.

[26]. Ehrbar, A. (1998). EVA - The Real Key to Creating Wealth. John Wiley \& Sons, Inc.

[27]. Fama, EF, \& French, K (1997), "Dividends, debts, investment and earnings" Unpublished manuscript.

[28]. Fernandez, P. (2001). EVA and Cash Value Added Do Not Measure Shareholder Value Creation.http://papers.ssrn.com/sol3/papers.cfm?

[29]. Fodil, A., Zeghal, D., \& Andaleeb, S. (2007). The Effect of Board's Quality on Performance: A Study of Canadian Firms. The Journal Corporate Governance, 15 (4), July, 2007, 623-635.

[30]. George, A. (2007). Value-Based Management, Eva and Stock Price Performance in Canada. The Journal of Management Decision, 45(9), 2007, 1397-1411.

[31]. Granger, C. W. J. (1969). Investigating Causal Relations by Econometric Models and Cross-Spectral Methods. Econometrica, July $1969,424-438$.

[32]. Grant, J. (1996). Foundation Of EVA For Investment Managers: Just In Time EVA. Journal of Financial Management, Fall 1996, 23(1), 41 .

[33]. Griffith, J. M. (2006). EVA ${ }^{\circledR}$ and Stock Performance. Journal of Investing, 15 (2) Summer 2006, 75.

[34]. Hamilton, R. (1777). An Introduction to Merchandize, Edinburgh

[35]. Irala, L.R. (2005). EVA: The Right Measure of Managerial Performance. Journal of Accounting and Finance, 19(2), April- Sept. $2005,77-87$.

[36]. Ismail, A. (2006). Is Economic Value Added More Associated With Stock Return Than Accounting Earnings? The UK Evidence. International Journal of Managerial Finance, 2 (4), 2006, 343-353.

[37]. Kim, W. G. (2006). EVA And Traditional Accounting Measure: Which Metric is Better Predictor of Market Value Of Hospitality Companies? Journal of Hospitality \& Tourism Research, 30(1), February 2006, 34-49.

[38]. Lehn, K., \& Makhija, A. K. (1997). EVA, Accounting Profits, and CEO Turnover: An Empirical Examination 1985-1994. Journal of Applied Corporate Finance, 10(2), 90-97.

[39]. Lehn, K., \& Makhija, A. K. (1996). EVA And MVA as Performance Measures and Signal for Strategic Change. The Journal of Strategy and Leadership, 24, May/ June, 1996, 34-38.

[40]. Leong, K., Marco, P., \& Janis K. Z. (2009). Portfolio Strategies Using EVA, Earnings Ratio or Book-To-Market is One Best. Review of Accounting and Finance, 8 (1), 76-86.

[41]. Luber, R. B. (1996). Who Are Real Wealth Creators? Fortune, Dec 9, 1996, 2-3.

[42]. Maditinos, D. I., Zeljko S., \& Nikolaos G. T. (2009). Modelling Traditional Accounting and Modern Value-Based Performance Measures to Explain Stock Market Returns in the Athens Stock Exchange (ASE). Journal of Modeling in Management, 4 (3), 182201.

[43]. Malik, M. (2004). EVA and Traditional Performance Measures Some Empirical Evidence. The Indian Journal of Commerce, 57(2), April- July 2004, 32-38.

[44]. Marshall, A. (1890). Principles of Economics. The Macmillan Press Ltd,

[45]. McCinville, D. (1994). How Much Value Are Adding. Management Accountant, August 1994, 610-11. 
[46]. Mir, A. E., \& Souad S. (2008). Corporate Governance and the Relationship between EVA and Created Shareholder Value. Corporate Governance, 8 (1), 46-58.

[47]. O’Byrne, S. F. (1996). EVA and Market Value. Journal of Applied Corporate Finance, 9(1), 116-125.

[48]. Padgett, T. (1996). Cold War of Idea of Banks Are Not Performers, American Bankers, July 24, $1996,1$.

[49]. Pal, K. and Garg, M. C, (2004). Disclosure of EVA in Indian Corporate. The Indian Journal of Commerce, 57(2), April- July 2004, 39-49.

[50]. Pattanayak, J.K., Mukherjee, K. (1998). Adding Value to Money. The Chartered Accountant, February $1998,8-12$.

[51]. Paulo, S. (2010). The UK Companies Act of 2006 and the Sarbanes-Oxley Act of 2002 Implications for EVA (Economic Value Added), International Journal of Law and Management, 52 (3), 173-181.

[52]. Peixoto, S. M. (2002). M. Application to Public Companies,http://paper.ssrn.com/sol13/paper.cfm?abstract_id=302687.

[53]. Peterson, P. P., Peterson D. R. (1996). Company performance and Measures of Value Added. The Research Foundation of the Institute of Chartered Financial Analysts.

[54]. Ralph, P. (2006). Further Evidence On The Information Content Of Economic Value Added. Review of Accounting and Finance, $5(3), 204-215$.

[55]. Riahi-Belkaoui, A. (1996). Earnings-Returns Relation versus Net-Value Added-Returns Relation: A Case for Nonlinear Specification. Advances in Quantitative Analysis of Finance and Accounting, 4(1), 175-185.

[56]. Rogerson, W.P. (1997). Intertemporal Cost Allocation and Managerial Investment Incentives: A Theory Explaining the Use of Economic Value Added as a Performance Measure. Journal of Political Economy, 105(4), 770-795.

[57]. Shapiro, S.S, and M.B. Wilk (1965),"'an analysis of variance Test of Normality (Complete Sample),'Biometric 52 (3/4) Dec 1965, pp.1-611

[58]. Solomons, D. (1965). Divisional Performance Measurement and Control. Homewood, Irwin.

[59]. Stewart, G.B. (1991). The Quest for Value, New York: Harper.

[60]. Stewart, G.B. (1994). EVA: Fact and Fantasy. Journal of Applied Corporate Finance, 7(2) 71-84.

[61]. Teitebaum, R. (1997). America's Greatest Wealth Creators. Fortune, November 10, 1997, 136(12), 265(5).

[62]. Todd, M. (1997). EVA's Charm as a Performance Measures. Business Standard, January 1997, 41-45.

[63]. Tong, Y., Chuang L., \& Xiaoke C. (2009).An Empirical Study on the Value Relevance of Economic Value Added in Logistics. Retrieved on August 10, 2010 at 11:33:12 UTC from IEEE Xplore.

[64]. Uyemura, D.G., Kantor, C.C., \& Petit, J.M. (1996). EVA for Banks: Value Creation, Risk Management, and Profitability Measurement. Journal of Applied Corporate Finance, 9 (2), 94-111.

[65]. Worthington, A. C. \& Tracey W. (2001).Economic Value Added: A Review of Theoretical and Empirical Literature. Asian Review of Accounting, 9 (1), 67-86. 